Journal of Organometallic Chemistry, 389 (1990) C7-C11

Elsevier Sequoia S.A., Lausanne - Printed in The Netherlands

JOM 20894PC

Preliminary communication

\title{
Synthesis and crystal structure of a pentanuclear heterometallic acetylide complex $\mathrm{Cp}_{2} \mathrm{Mo}_{2} \mathrm{Ru}_{3}(\mathrm{CO})_{10}(\mathrm{C} \equiv \mathrm{CPh})_{2}$
}

\author{
Der-Kweng Hwang, Yun Chi * \\ Department of Chemistry, National Tsing Hua University, Hsinchu 30043 (Taiwan) \\ Shie-Ming Peng and Gene-Hsiang Lee \\ Department of Chemistry, National Taiwan University, Taipei 10764 (Taiwan) \\ (Received March 22nd, 1990)
}

\begin{abstract}
The pentanuclear heterometallic acetylide complex $\mathrm{Cp}_{2} \mathrm{Mo}_{2} \mathrm{Ru}_{3}(\mathrm{CO})_{10}(\mathrm{C} \equiv \mathrm{CPh})_{2}$ (3) was prepared by the reaction of the metal acetylide $\mathrm{CpMo}(\mathrm{CO})_{3} \mathrm{C} \equiv \mathrm{CPh}$ with $\mathrm{Ru}_{3}(\mathrm{CO})_{12}$. This complex was characterized by spectroscopic methods and by $\mathrm{X}$-ray single-crystal structure determination. Notable structural features of the new complex 3 include an unusual symmetric pentametallic double butterfly skeleton and a novel $\mu_{4}-\eta^{2}$ bonding mode for the acetylide ligand. Crystal data for 3: space group $P 2_{1} / c ; a$ 24.119(10), b 20.739(4), c 15.358(3) $\AA, \quad \beta 101.68(4)^{\circ}, Z=8$; final $R=0.038, R_{\mathrm{w}}=0.034$ and $\mathrm{GOF}=1.57$.
\end{abstract}

Heterometallic transition metal chemistry has experienced rapid growth for many years [1]. One of the key factors is due to the belief that cooperative effects between different metal atoms may promote unique patterns of substrate activation. In seeking to develop a systematic method to synthesize mixed-metal complexes by using the concept of isolobal analogy [2], Stone and coworkers have used alkylidyne derivatives $\mathrm{Cp}(\mathrm{CO})_{2} \mathrm{~W} \equiv \mathrm{CR}$ to prepare many mixed-metal clusters containing a bridging alkylidyne fragment [3]. Recently, a few research groups have started to use transition metal acetylide complexes $\mathrm{L}_{n} \mathrm{MC} \equiv \mathrm{CR}$ in attempts to prepare heterometallic clusters containing a multisite cluster-bound acetylide fragment [4].

We have performed the reaction between $\mathrm{CpW}(\mathrm{CO})_{3} \mathrm{C} \equiv \mathrm{CPh}$ and the triosmium derivative $\mathrm{Os}_{3}(\mathrm{CO})_{10}(\mathrm{NCMe})_{2}$ [5]. Two heterometallic acetylide complexes, $\mathrm{CpWOs}_{3}(\mathrm{CO})_{11}(\mathrm{C} \equiv \mathrm{CPh})(1)$ and $\mathrm{CpWOs}_{2}(\mathrm{CO})_{8}(\mathrm{C} \equiv \mathrm{CPh})(2)$, have been isolated and characterized by $\mathrm{X}$-ray crystal structure determination (Scheme 1). However, the analogous reaction with $\mathrm{Ru}_{3}(\mathrm{CO})_{12}$ failed to produce the analogous tetranuclear derivative, but provided only the trinuclear complex [6]. In this paper, we report the preparation and crystal structure of an analogous pentanuclear heterometallic 


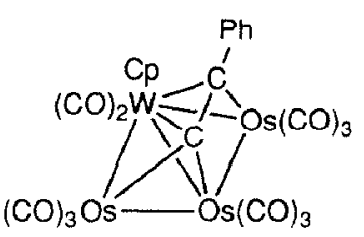

(1)

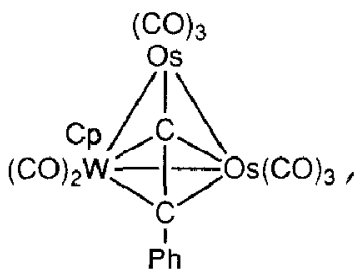

(2)

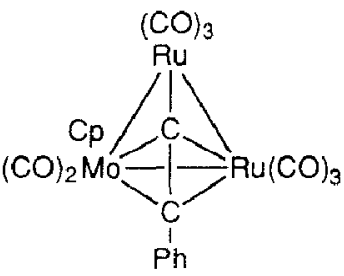

(4)

Scheme 1

derivative $\mathrm{Cp}_{2} \mathrm{Mo}_{2} \mathrm{Ru}_{3}(\mathrm{CO})_{10}(\mathrm{C} \equiv \mathrm{CPh})_{2}(3)$, generated by condensation of $\mathrm{CpMo}$ $(\mathrm{CO})_{3} \mathrm{C} \equiv \mathrm{CPh}$ with $\mathrm{Ru}_{3}(\mathrm{CO})_{12}$. Notable structural features of the new complex 3 include an uncommon symmetrical pentametallic double butterfly skeleton [7] and a novel $\mu_{4}-\eta^{2}$ bonding mode for the acetylide ligand [5].

Treatment of a mixture of $\mathrm{Ru}_{3}(\mathrm{CO})_{12}$ and $\mathrm{CpMo}(\mathrm{CO})_{3} \mathrm{C} \equiv \mathrm{CPh}$ in a molar ratio $2: 3$ in refluxing toluene under nitrogen for $40 \mathrm{~min}$, followed by thin-layer chromatography on silica gel $\left(\mathrm{CH}_{2} \mathrm{Cl}_{2}\right.$ : hexane $\left.=2: 3\right)$, gave the expected trinuclear acetylide derivative $\mathrm{CpMoRu}{ }_{2}(\mathrm{CO})_{8}(\mathrm{C} \equiv \mathrm{CPh})(4,42 \%)$, unreacted $\mathrm{Ru}_{3}(\mathrm{CO})_{12}(7 \%)$, and small proportions of dark-brown complex $3(5 \%)$. The complex 3 was identified primarily from its spectroscopic data: FAB MS ( $\left.{ }^{102} \mathrm{Ru},{ }^{98} \mathrm{Mo}\right): m / z 1114\left(M^{+}\right)$; $\mathrm{IR}\left(\mathrm{CCl}_{4}\right): \nu$ (CO), 2073 (vs), 2054 (s), 2014 (m, br), 1986 (w), 1973 (w), 1940 (vw) $\mathrm{cm}^{-1} ;{ }^{1} \mathrm{H}$ NMR $\left(300 \mathrm{MHz}, \mathrm{CDCl}_{3}, 294 \mathrm{~K}\right): \delta 7.56(\mathrm{~d}, 4 \mathrm{H}, J(\mathrm{H}-\mathrm{H})=7.1 \mathrm{~Hz}), 7.42$ $(\mathrm{t}, 4 \mathrm{H}, J(\mathrm{H}-\mathrm{H})=7.3 \mathrm{~Hz}), 7.30(\mathrm{t}, 2 \mathrm{H}, J(\mathrm{H}-\mathrm{H})=7.3 \mathrm{~Hz}), 5.23(\mathrm{~s}, 10 \mathrm{H}) ;{ }^{13} \mathrm{C} \mathrm{NMR}$ $\left(75 \mathrm{MHz}_{2} \mathrm{CDCl}_{3}, 294 \mathrm{~K}\right): \delta 238.1(\mathrm{Mo}-\mathrm{CO}, 2 \mathrm{C}), 198.9(\mathrm{Ru}-\mathrm{CO}, 2 \mathrm{C}), 196.9$ (Ru-CO, 2C), $195.8(\mathrm{Ru}-\mathrm{CO}, 2 \mathrm{C}), 193.3(\mathrm{Ru}-\mathrm{CO}, 2 \mathrm{C})$. The ${ }^{1} \mathrm{H}$ and ${ }^{13} \mathrm{C} \mathrm{NMR}$ spectra and the parent ion in the mass spectrum suggest the presence of two identical acetylide ligands and two identical CpMo units. Cluster complexes possessing such high molecular symmetry are rather uncommon.

Precise structural details have been provided by $\mathrm{X}$-ray analysis. Crystals suitable for single-crystal X-ray diffraction study were obtained from a solution in $\mathrm{CH}_{2} \mathrm{Cl}_{2} / \mathrm{CH}_{3} \mathrm{OH}$ at room temperature. According to the $\mathrm{X}$-ray structure determination, the asymmetric unit contains two crystallographically distinct, but structurally similar molecules [8*]. An ORTEP diagram of one of these molecules is shown in Fig. 1, together with selected bond distances and angles. The molecule crystallizes in the monoclinic space group $\mathrm{P}_{2} / \mathrm{c}$ with the presence of one independent $\mathrm{CH}_{2} \mathrm{Cl}_{2}$ molecule. There is no interaction between the cluster complexes nor between the

\footnotetext{
* Reference number with asterisk indicates a note in the list of references.

Fig. 1. Molecular structure of $\mathrm{CP}_{2} \mathrm{MO}_{2} \mathrm{Ru}_{3}(\mathrm{CO})_{10}(\mathrm{C} \equiv \mathrm{CPh})_{2}(3)$ showing the atomic numbering scheme. Important dimensions include: bond lengths $(\AA)$ : $\operatorname{Mo}(1 \mathrm{~A})-\operatorname{Mo}(2 \mathrm{~A}) 3.063(2), \operatorname{Mo}(1 \mathrm{~A})-\operatorname{Ru}(1 \mathrm{~A}) 2.830(2)$, $\operatorname{Mo}(1 \mathrm{~A})-\operatorname{Ru}(2 \mathrm{~A}) \quad 2.729(1), \quad \operatorname{Mo}(2 \mathrm{~A})-\operatorname{Ru}(2 \mathrm{~A}) \quad 2.755(2), \quad \operatorname{Mo}(2 \mathrm{~A})-\mathrm{Ru}(3 \mathrm{~A}) \quad 2.822(2), \quad \operatorname{Ru}(1 \mathrm{~A})-\mathrm{Ru}(2 \mathrm{~A})$ 2.778(2), $\operatorname{Ru}(2 \mathrm{~A})-\operatorname{Ru}(3 \mathrm{~A})$ 2.770(2), $\mathrm{Mo}(1 \mathrm{~A})-\mathrm{C}(21 \mathrm{~A}), 2.22(1), \operatorname{Mo}(2 \mathrm{~A})-\mathrm{C}(21 \mathrm{~A}) 1.99(1), \operatorname{Ru}(2 \mathrm{~A})-\mathrm{C}(21 \mathrm{~A})$ 2.146(9), $\mathrm{Mo}(1 \mathrm{~A})-\mathrm{C}(22 \mathrm{~A})$ 2.303(9), $\mathrm{Ru}(1 \mathrm{~A})-\mathrm{C}(22 \mathrm{~A}) 2.11(1), \mathrm{C}(21 \mathrm{~A})-\mathrm{C}(22 \mathrm{~A}), 1.37(1), \mathrm{Mo}(1 \mathrm{~A})-\mathrm{C}(29 \mathrm{~A})$, 2.02(1), $\mathrm{Mo}(2 \mathrm{~A})-\mathrm{C}(29 \mathrm{~A}) 2.25(1), \operatorname{Ru}(2 \mathrm{~A})-\mathrm{C}(29 \mathrm{~A}) 2.14(1), \mathrm{Mo}(2 \mathrm{~A})-\mathrm{C}(30 \mathrm{~A}) 2.28(1) . \mathrm{Ru}(3 \mathrm{~A})-\mathrm{C}(30 \mathrm{~A})$ 2.12(1), C(29A)-C(30A) 1.36(1), $\mathrm{Mo}(1 \mathrm{~A})-\mathrm{C}(1 \mathrm{~A})$ 2.00(1), $\mathrm{Ru}(1 \mathrm{~A})-\mathrm{C}(1 \mathrm{~A}) 2.33(1), \mathrm{Mo}(2 \mathrm{~A})-\mathrm{C}(2 \mathrm{~A}) 2.01(1)$, $\mathrm{Ru}(3 \mathrm{~A})-\mathrm{C}(2 \mathrm{~A})$ 2.36(1); bond angles $\left({ }^{\circ}\right)$ : $\mathrm{Mo}(1 \mathrm{~A})-\mathrm{C}(1 \mathrm{~A})-\mathrm{O}(1 \mathrm{~A})$ 152.9(9), Ru(1A)-C(1A)-O(1A) 125.4(8), $\mathrm{Mo}(2 \mathrm{~A})-\mathrm{C}(2 \mathrm{~A})-\mathrm{O}(2 \mathrm{~A}) 152.9(9), \mathrm{Ru}(3 \mathrm{~A})-\mathrm{C}(2 \mathrm{~A})-\mathrm{O}(2 \mathrm{~A}) 126.6(8)$.
} 


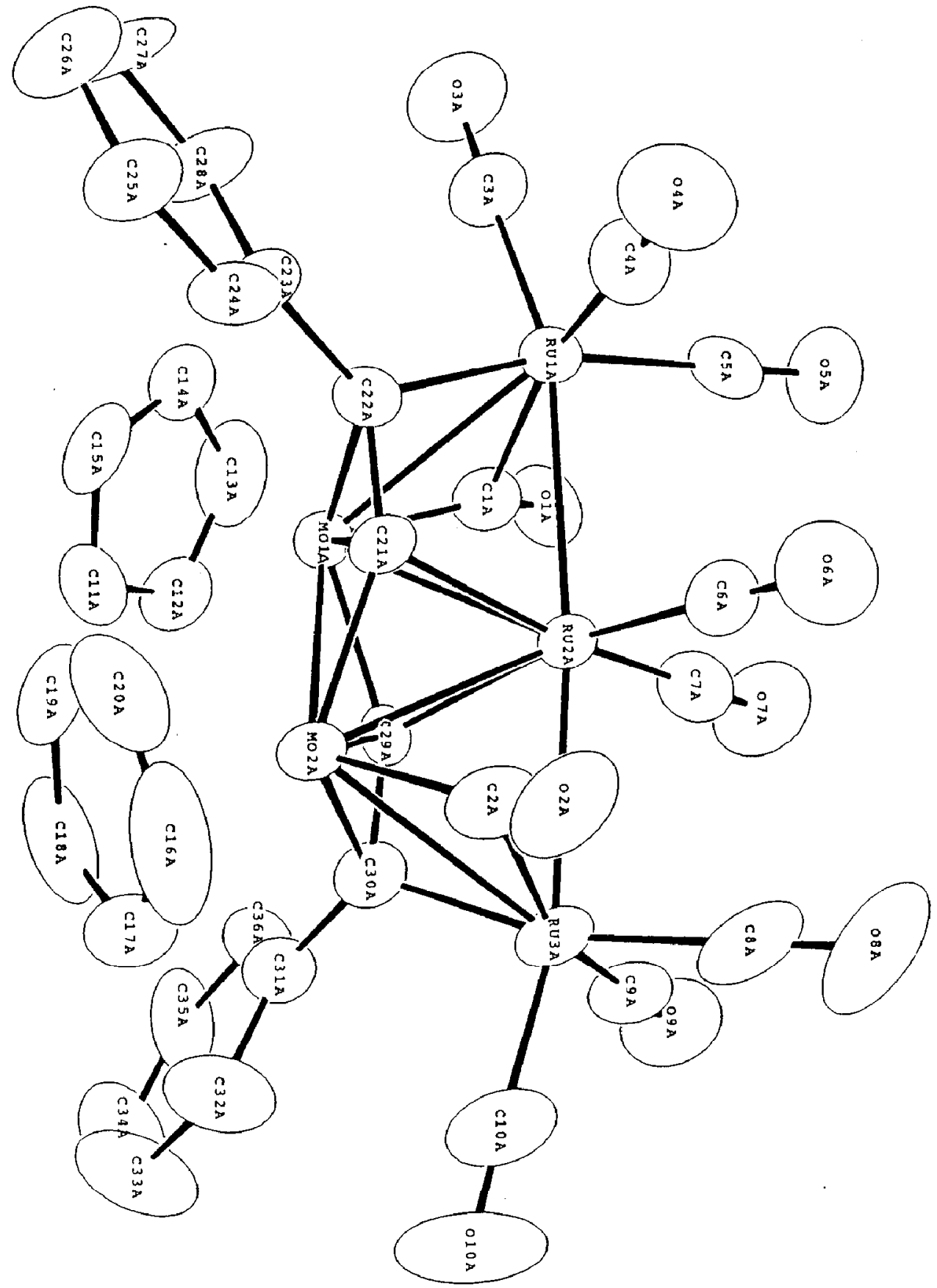




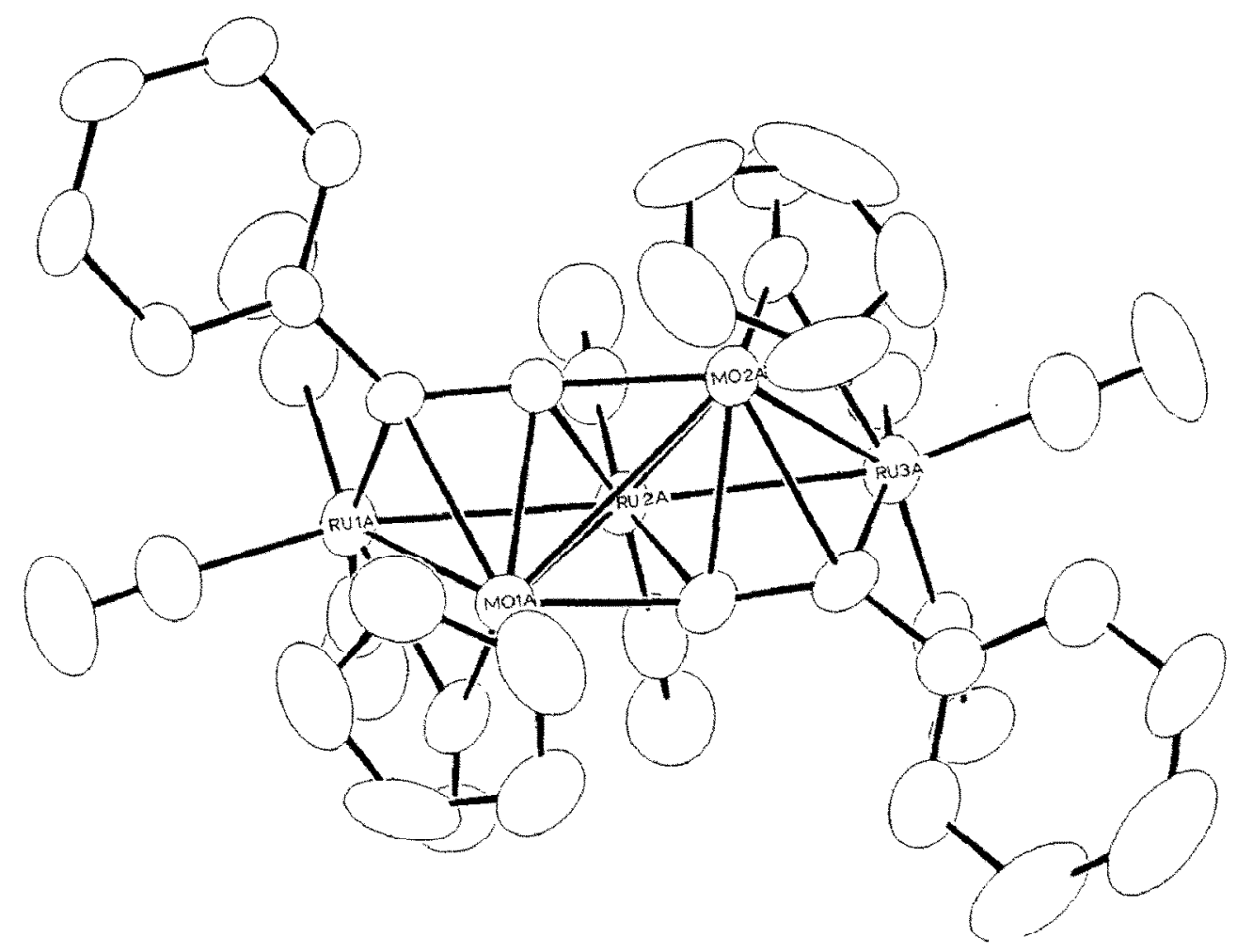

Fig. 2. An ORTEP view of 3 showing the $C_{2}$ rotational symmetry of this molecule.

cluster and the solvent molecules. The $\mathrm{Mo}_{2} \mathrm{Ru}_{3}$ cluster core adopts a novel double butterfly geometry [7], as expected for the pentametallic complexes characterized by the presence of 76 outer valence electrons [9]. Atoms $\mathrm{Ru}(2 \mathrm{~A}), \mathrm{Mo}(1 \mathrm{~A})$ and $\mathrm{Mo}(2 \mathrm{~A})$ constitute the metal triangle located in the center, of which the ruthenium atom $\operatorname{Ru}(2 \mathrm{~A})$ associates with two terminal CO ligands and each molybdenum atom associates with one bridging $\mathrm{CO}$ ligand and one $\mathrm{Cp}$ ligand. There are two further ruthenium atoms, $R u(1 \mathrm{~A})$ and $R u(3 \mathrm{~A})$, each of which is located on one the two $\mathrm{Ru}-$-Mo edges of the central triangle and is coordinated by three terminal $\mathrm{CO}$ ligands. Furthermore, the arrangement of the transition metal atoms and their surrounding ligands of this molecule suggests that there is a $C_{2}$ rotational axis which passes the $R u(2 A)$ atom and the middle of the $M o(1 \mathrm{~A})-\mathrm{Mo}(2 \mathrm{~A})$ vector. A side-view of this molecule, which emphasizes the $C_{2}$ symmetry, is depicted in Fig. 2.

Due to the existence of $C_{2}$ symmetry, the acetylide ligands, $\mathrm{C}(21 \mathrm{~A})-\mathrm{C}(22 \mathrm{~A})$ and $\mathrm{C}(29 \mathrm{~A})-\mathrm{C}(30 \mathrm{~A})$, occupy opposite faces of the $\mathrm{Mo}_{2} \mathrm{Ru}$, butterfly skeleton related by a $180^{\circ}$ rotation, and are coordinated in multisite fashion with each $\alpha$-carbon bound to the three center metal atoms $M \circ(1 A), M o(2 A)$ and $R u(2 A)$, and with the $\beta$-carbon atom bridged to the Mo-Ru bond at the edge. The dihedral angles between the planes $M o(1 A)-M o(2 A)-R u(2 A)$ and $M o(1 A)-R u(1 A)-R u(2 A)$ and between the planes $M o(1 \mathrm{~A})-\mathrm{Mo}(2 \mathrm{~A})-\mathrm{Ru}(2 \mathrm{~A})$ and $\mathrm{Mo}(2 \mathrm{~A})-\mathrm{Ru}(2 \mathrm{~A})-\mathrm{Ru}(3 \mathrm{~A})$ are 132.72(4) and $135.59(4)^{\circ}$, respectively. The $\mu_{4}-\eta^{2}$ bonding mode of the acetylide ligand is of interest. The related $\mu_{4}-\eta^{2}$ bonding interaction has been reported in the 
spiked triangular $\mathrm{Ni}_{2} \mathrm{Fe}_{2}$ and $\mathrm{FeRuCO} \mathrm{CO}_{2}$ complexes, [10] the square pyramidal $\mathrm{Ru}_{5}$ complex [11] and the wing-tip bridged butterfly $\mathrm{NiRu}_{4}$ complex [12]. However, the pentametallic derivative 3 and the tetranuclear complex 1 represent rare examples, in which the acetylide lies on the face of the tetrametallic butterfly skeleton and adopts a $1 \sigma+2 \pi$ bonding interaction [13] supplying a total of five electrons to the cluster orbitals. Tetranuclear $\mathrm{Fe}_{4}$ and $\mathrm{Ru}_{4}$ nitrile complexes which possess similar $\mu_{4}-\eta^{2}$ bonding interactions have been documented [14].

The mechanism for the formation of 3 is unknown at present. However, it is reasonable to propose that the mechanism involves the generation of a tetrametallic intermediate $\mathrm{CpMoRu} \mathrm{u}_{3}(\mathrm{CO})_{11}(\mathrm{C} \equiv \mathrm{CPh})$ with a structure similar to 1 , followed by further condensation with $\mathrm{CpMo}(\mathrm{CO})_{3} \mathrm{C} \equiv \mathrm{CPh}$ to give the isolated product. Unfortunately, no such species was observed during the reaction, suggesting that the proposed intermediate may be unstable under the conditions studied.

Acknowledgement. We are grateful to the National Science Council of the Republic of China for financial support (Grant NO. NSC79-2008-M007-52).

\section{References}

1 D.A. Roherts and G.I. Geoffroy, in: G. Wilkinson, F.G.A. Stone and E.W. Abel (Eds.), Comprehensive Organometallic Chemistry, Pergamon Press, Oxford, 1982, Vol. 6, Chap. 40.

2 (a) R. Hoffmann, Angew. Chem. Int. Ed. Engl, 21 (1982) 711. (b) F.G.A. Stone, Angew. Chem. Int. Ed. Engl., 23 (1984) 89.

3 (a) F.G.A. Stone, in: M.H. Chisholm, (Ed.), Inorganic Chemistry: Toward the 21st Century, ACS Symp. Ser. No 211, American Chemical Society, Washington, DC, 1983, p 383. (b) S.J. Davies, J.A.K. Howard, R.J. Musgrove and F.G.A. Stone, Angew. Chem. Int. Ed. Engl., 28 (1989) 624 and references cited therein.

4 (a) E. Roland, W. Bernhardt and H. Vahrenkamp, Chem. Ber., 119 (1986) 256. (b) W. Bernhardt and H. Vahrenkamp, Organometallics, 5 (1986) 2388. (c) A.J. Deeming, S. Donovan-Mtunzi and K. Hardcastle, J. Chem. Soc., Dalton Trans., (1986) 543. (d) A.A. Koridze, A. Kizas, Yu.T. Struchkov, A.I. Yanovakii and N.E. Kolobova, Metalloorg. Khim., 1 (1988) 831. (e) H. Vahrenkamp, Pure Appl. Chem., 61 (1989) 1777. (f) P.M. Fritz, K. Polborn, M. Steimann and W. Beck. Chem. Ber., 122 (1989) 889. (g) Y. Chi, D.-K. Hwang, S.-F. Chen and L.-K. Liu, J. Chem. Soc., Chem. Commun., (1989) 1540.

5 Y. Chi, G.-H. Lee, S.-M. Peng and C.-H. Wu, Organometallics, 8 (1989) 1574.

6 Y. Chi, S.-M. Peng, G.-H. Lee and B.-J. Liu, Polyhedron, 8 (1989) 2003.

7 E. Sappa, A. Tiripicchio, A.J. Carty and G.E. Toogood, Prog. Inorg. Chem., 35 (1987) 437.

8 Selected crystal data for 3: $\mathrm{C}_{36} \mathrm{H}_{20} \mathrm{Mo}_{2} \mathrm{O}_{10} \mathrm{Ru}_{3} \cdot \frac{1}{2} \mathrm{CH}_{2} \mathrm{Cl}_{2}, \quad M=1150.1$, monoclinic, space group

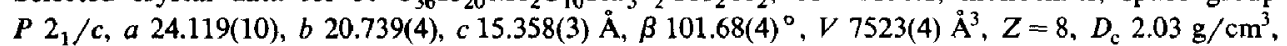
$F(000)=4422.9$, Mo- $K_{\alpha}$ radiation with $\lambda 0.70930 \AA, \Psi$ scan absorption correction was made and 9816 unique reflections were measured of which 6262 were considered observed with $I>2 \sigma(I)$. The structure was solved by a direct method and refined by full matrix least-squares refinement. Final $R=0.038, R_{\mathrm{w}}=0.034$ and $\mathrm{GOF}=1.57$. Tables of bond distances and angles, a table of positional parameters and anisotropic thermal parameters, and listings of the observed and calculated structural factors are available from the authors.

9 D.M.P. Mingos, Acc. Chem. Res., 17 (1984) 311.

10 (a) C. Weatherell, N.J. Taylor, A.J. Carty, E. Sappa and A. Tiripicchio, J. Organomet. Chem., 291 (1985) C9. (b) E. Roland and H. Vahrenkamp, Organometallics, 2 (1983) 1048.

11 A.J. Carty, S.A. MacLaughlin and N.J. Taylor, J. Am. Chem. Soc., 103 (1981) 2456.

12 M. Lanfranchi, A. Tiripicchio, E. Sappa, S.A. Maclaughlin and A.J. Carty, J. Chem. Soc., Chem. Commun. (1982) 538.

13 E. Sappa, A. Tiripicchio and P. Braunstein, Chem. Rev., 83 (1983) 203.

14 (a) H. Bantel, B. Hansert, A.K. Powell, M. Tasi and H. Vahrenkamp, Angew Chem. Int. Ed. Engl., 28 (1989) 1059. (b) E. Keller and D. Wolters, Chem. Ber., 117 (1984) 1572. 